\title{
STUDIES ON THE HEAVY METAL REMOVAL EFFICIENCY AND ANTIBACTERIAL ACTIVITY OF 2-(DIPHENYLPHOSPHINO)AMINOPYRIDINE
}

\author{
Özlem Sarıöz ${ }^{1^{*}}$, Burcu Malgaç ${ }^{1}$, Yavuz Sürme ${ }^{1}$, Sedef İlk², Muhsin Karaarslan ${ }^{3}$ \\ ${ }^{1}$ Department of Chemistry, Faculty of Science and Arts, Nigde Ömer Halisdemir University, Nigde, Turkey \\ ${ }^{2}$ Central Research Laboratory, Nigde Ömer Halisdemir University, Nigde, Turkey \\ ${ }^{3}$ Department of Chemistry, Faculty of Science and Arts, Aksaray University, Aksaray, Turkey \\ *ozsarioz4@yahoo.com \\ burcu.malgac@gmail.com; ysurme@ohu.edu.tr; sedefilk@ohu.edu.tr; muhsinkaraarslan@gmail.com
}

The solvent extraction of metal picrates such as $\mathrm{Ni}^{2+}, \mathrm{Cu}^{2+}, \mathrm{Co}^{2+}, \mathrm{Pb}^{2+}$ and $\mathrm{Cd}^{2+}$ from the aqueous to the organic phase was studied using 2-(diphenylphosphino)aminopyridine $\left(\mathrm{Ph}_{2} \mathrm{PNHpy}\right)$. The effects of parameters including the $\mathrm{pH}$ of the aqueous phase and the ligand solution volume were investigated to determine the extraction ability of the ligand for metal ions. The results showed that the extraction percentages of metal ions were high at low $\mathrm{pH}$ values. The antibacterial activity of the aminophosphine was also screened against Escherichia coli (E. coli) ATCC 25922, Staphylococcus aureus (S. aureus) ATCC 25923, Pseudomonas syringae $p v$. tomato ( $P$. syringae) DC300, Salmonella enterica serotype Typhmurium (S. typhmurium) SL 1344 and Streptococcus mutans (S. mutans) ATCC 25175. From the studies of antibacterial activity, it was observed that the ligand exhibited a potent inhibitory effect against all Gram-negative and Gram-positive bacteria with a diameter of inhibition zone ranging from 3.86 to $18.10 \mathrm{~mm}$. The aminophosphine ligand $\left(\mathrm{Ph}_{2} \mathrm{PNHpy}\right)$ should be considered as a suitable bio-active molecule for antimicrobial material design and next-generation, non-toxic drug fabrication. $\mathrm{The}^{\mathrm{Ph}}{ }_{2} \mathrm{PNHpy}$ obtained may have the potential for use as an antimicrobial additive for bioengineering applications.

Keywords: aminophosphines; heavy metals; solvent extraction; antibacterial activity

\section{ИСПИТУВАЊЕ НА ЕФИКАСНОСТА НА ОТСТРАНУВАњЕ НА ТЕШКИ МЕТАЛИ И АНТИБАКТЕРИСКОТО ДЕЈСТВО НА 2-(ДИФЕНИЛФОСФИНО)АМИНОПИРИДИН}

Испитувана е екстракцијата на металните пикрати на $\mathrm{Ni}^{2+}, \mathrm{Cu}^{2+}, \mathrm{Co}^{2+}, \mathrm{Pb}^{2+}$ и $\mathrm{Cd}^{2+}$ од водни раствори до органската фаза со употреба на 2-(дифенилфосфино)аминопиридин $\left(\mathrm{Ph}_{2} \mathrm{PNHpy}\right)$. Беше испитано влијанието на параметрите како што се $\mathrm{pH}$ на водната фаза и волуменот на растворот на лигандот за да се определи способноста на лигандот за екстракција на метални јони. Резултатите покажуваат дека уделот на екстракција е поголем при пониски вредности на $\mathrm{pH}$. Антибактериска активност на аминофосфинот беше испитана на Escherichia coli (E. coli) ATCC 25922, Staphylococcus aureus (S. aureus) ATCC 25923, Pseudomonas syringae pv. tomato (P. syringae) DC300, Salmonella enterica serotype Typhmurium (S. typhmurium) SL 1344 и на Streptococcus mutans (S. mutans) АТCC 25175. Од истражувањето на антибактериската активност беше утврдено дека лигандот има силно инхибиторно дејство врз сите Грам-негативни и Грам-позитивни бактерии со пречник на инхибиторна зона во опсегот од 3,86 до $18,10 \mathrm{~mm}$. Аминофосфинскиот лиганд $\left(\mathrm{Ph}_{2} \mathrm{PNHpy)}\right.$ треба да се земе предвид како соодветна биомолекула за дизајнирање на антимикорбни материи и производство на нетоксични лекови од следна генерација. Добиениот $\mathrm{Ph}_{2} \mathrm{PNHpy} \mathrm{може} \mathrm{да} \mathrm{има} \mathrm{потенцијал} \mathrm{како} \mathrm{антимикробен} \mathrm{адитив} \mathrm{за} \mathrm{биоинженерски} \mathrm{апликации.}$

Клучни зборови: аминофосфини; тешки метали; екстракција со растворувач; антибактериска активност 


\section{INTRODUCTION}

Heavy metal ions are extensively used in industrial applications and are among the most common environmental pollutants $[1,2]$. Some metals, such as $\mathrm{Fe}, \mathrm{Zn}, \mathrm{Cu}, \mathrm{Co}, \mathrm{Cr}, \mathrm{Mn}$ and $\mathrm{Ni}$, play an essential role in metabolism for humans and animals in trace amounts, but higher concentrations can cause toxicity and health hazards [3, 4]. Others, such as $\mathrm{Pb}$ and $\mathrm{Cd}$, are not suitable for biological functions and can cause many health complications, even at very low concentrations [57]. Waste materials containing heavy metals are considered hazardous materials. Heavy metal ion contamination of water is one of the most important environmental concerns. The heavy metal ions in wastewater are detrimental to soil, underground water and surface water, with destructive effects on ecology and the health of animals and humans if not properly treated [8]. Therefore, the recovery of heavy metals is necessary and important to protect the environment. In recent years, various methods for heavy metal removal have been extensively studied due to the potential health and ecological hazards. Among the available processing alternatives, solvent extraction offers a convenient solution to the problem and has been widely used for the extraction and separation of heavy metals from the aqueous phase $[6,9,10]$. Solvent extraction techniques are among the most studied method for the recovery of various metals ions from different sources due to their ease, simplicity, speed and wide scope $[11,12]$.

There are a number of efficient reagents used for metal extraction, most notably organophosphorus compounds [13-23] and amines [24]. The synergistic extraction of these divalent transition metal ions with mixtures of neutral organophosphorus extractants and amine extractants has been reported previously [25].

Aminophosphine ligands containing direct $\mathrm{P}-\mathrm{N}$ bonds may be constructed in large quantities through the use of relatively simple condensation processes and from inexpensive starting materials [26]. Despite this, there are limited studies focusing on the potential use of aminophosphines, that combine neutral organic phosphorus derivatives and amines, in the extraction of metal ions [27]. In this study, bidentate aminophosphine ligand, 2(diphenylphosphino)aminopyridine $\left(\mathrm{Ph}_{2} \mathrm{PNHpy}\right)$, that incorporates both pyridyl and phosphine groups was investigated as a ligand in the solvent extraction of metal picrates such as $\mathrm{Ni}^{2+}, \mathrm{Cu}^{2+}$, $\mathrm{Co}^{2+}, \mathrm{Pb}^{2+}$ and $\mathrm{Cd}^{2+}$ from water. Furthermore, it is known that both pyridine [28-31] and aminophosphine derivatives [32-34] have exhibited a variety of biological activities. Consequently, the antibacterial effects of the aminophosphine containing a pyridyl group were investigated in Gram-positive and Gram-negative bacteria.

\section{RESULTS AND DISCUSSION}

2-(diphenylphosphino)aminopyridine was prepared as described previously by reacting 2aminopyridine with chlorodiphenylphosphine in the presence of triethylamine (Fig. 1) [35]. The spectroscopic data are consistent with those reported in the literature [36].

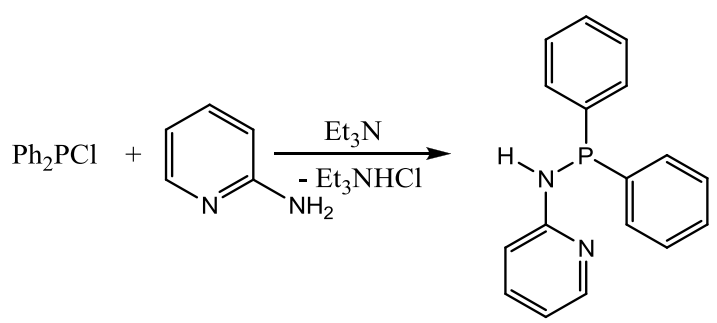

Fig. 1. Synthesis of 2-(diphenylphosphino)aminopyridine

The metal ion binding properties of 2(diphenylphosphino)aminopyridine were investigated using solvent extraction experiments in order to determine the extractability of metal ions including $\mathrm{Ni}^{2+}, \mathrm{Cd}^{2+}, \mathrm{Cu}^{2+}, \mathrm{Co}^{2+}$ and $\mathrm{Pb}^{2+}$ from the aqueous phase to the organic phase. Dichloromethane has a high dielectric constant and is favoured for the extraction of metal ions. Also, the aminophosphine ligand $\left(\mathrm{Ph}_{2} \mathrm{PNHpy}\right)$ was completely soluble in dichloromethane. Therefore, dichloromethane was chosen as the solvent for the extraction procedure. The results related to the extractability of the abovementioned metal picrates from the aqueous phase to the organic phase are given in Table 1 . The maximum extraction percentage $(\mathrm{E} \%)$ values of $\mathrm{Ni}^{2+}, \mathrm{Cd}^{2+}, \mathrm{Co}^{2+}$ and $\mathrm{Pb}^{2}$ picrates were $97.9 \%, 99.3 \%, 98.5 \%$ and $97.1 \%$, respectively, at $\mathrm{pH} 2$, while the maximum $\mathrm{E} \%$ value of copper picrate was $94.5 \%$ at $\mathrm{pH} 5$.

As can be seen from the data in Table 1, the ligand had a high extraction efficiency for the metal ions. Aminophosphines containing direct $\mathrm{P}-\mathrm{N}$ bonds are "soft-hard hybrid donor" ligands. Moreover, the introduction of the additional "soft donor" (nitrogen of the pyridine ring) to the structure enhances the extraction ability of the ligand toward soft and borderline metal cations such as $\mathrm{Cd}^{2+}$, $\mathrm{Ni}^{2+}, \mathrm{Cu}^{2+}, \mathrm{Co}^{2+}$ and $\mathrm{Pb}^{2+}$ [37]. Although 2(diphenylphosphino)aminopyridine displays a va- 
riety of coordination modes to metal centres, the ligand prefers simple chelation over bridging or monodentate P-bound coordination modes, and forms a strong five-membered $\mathrm{P}, \mathrm{N}$ chelate $[26,36$, 38-41]. In our experiments, the high extraction efficiency of this ligand can be explained by the chelate effect of the two donors. Also, it is known that 2-(diphenylphosphino)aminopyridine exists as hydrogen bonded dimers and can form hydrogenbonded metal complexes [33, 36, 42]. Because the relative stability of the metal complexes is affected, the hydrogen bonds also play an important role in the solvent extraction of metal ions [43].

\section{Table 1}

Effect of the $\mathrm{pH}$ of the aqueous phase on the extraction of $2 \times 10^{-4} \mathrm{M}$ metal picrates

\begin{tabular}{lccccc}
\hline \hline \multirow{2}{*}{$\mathrm{pH}$} & \multicolumn{5}{c}{$\mathrm{E} \%$} \\
\cline { 2 - 6 } & $\mathrm{Ni}^{2+}$ & $\mathrm{Cd}^{2+}$ & $\mathrm{Cu}^{2+}$ & $\mathrm{Co}^{2+}$ & $\mathrm{Pb}^{2+}$ \\
\hline 2 & $97.9 \pm 0.2$ & $99.3 \pm 0.3$ & $88.9 \pm 7.4$ & $98.5 \pm 0.2$ & $97.1 \pm 2.3$ \\
3 & $90.6 \pm 0.4$ & $89.6 \pm 0.3$ & $92.9 \pm 1.4$ & $98.2 \pm 0.2$ & $95.4 \pm 0.6$ \\
4 & $87.2 \pm 2.0$ & $88.0 \pm 0.8$ & $94.2 \pm 1.1$ & $96.1 \pm 0.6$ & $85.6 \pm 0.4$ \\
5 & $95.2 \pm 0.2$ & $84.4 \pm 3.3$ & $94.5 \pm 0.5$ & $93.4 \pm 0.4$ & $78.2 \pm 1.3$ \\
6 & $79.1 \pm 1.9$ & $80.6 \pm 5.1$ & $67.2 \pm 6.8$ & $92.9 \pm 6.0$ & $77.7 \pm 6.1$ \\
7 & $83.4 \pm 0.2$ & $69.3 \pm 2.5$ & $67.8 \pm 11.4$ & $82.7 \pm 8.9$ & $77.1 \pm 9.3$ \\
8 & $71.1 \pm 1.0$ & $61.0 \pm 3.2$ & $81.6 \pm 3.6$ & $72.7 \pm 2.4$ & $63.9 \pm 6.5$ \\
9 & $75.1 \pm 1.8$ & $57.1 \pm 1.7$ & $87.2 \pm 6.0$ & $56.8 \pm 1.5$ & $51.1 \pm 1.7$ \\
10 & $22.7 \pm 2.4$ & $55.7 \pm 5.9$ & $75.2 \pm 3.3$ & $54.7 \pm 2.9$ & $48.2 \pm 3.0$ \\
\hline \hline
\end{tabular}

In our previous paper [27], we reported the maximum $\mathrm{E} \%$ values of lead, copper and nickel picrates for $\mathrm{N}$-(diphenylphosphino)-4-methylpiperazin-1-amine as $71.8 \%, 74.7 \%$ and $76.9 \%$, respectively. Experimental results revealed that the bidentate ligand 2-(diphenylphosphino)aminopyridine showed better efficiency and affinity for $\mathrm{Cu}^{2+}$, $\mathrm{Ni}^{2+}$ and $\mathrm{Pb}^{2+}$ ions with respect to the monodentate ligand $N$-(diphenylphosphino)-4-methylpiperazin1 -amine.

The metal ion extraction was studied with the simultaneous determination of metal ions in the aqueous phase at different $\mathrm{pH}$ levels. The $\mathrm{pH}$ level was clearly an important parameter in the extraction process of metal ions. Table 1 shows the dependence of recovery on the $\mathrm{pH}$ of the solution. According to our results, 2-(diphenylphosphino) aminopyridine was effective for the extraction of metal ions at $\mathrm{pH} 2$. In most industrial processes cadmium is present in acidic solutions, and therefore it is necessary to use an extractant that can extract cadmium under these conditions [44]. Nickel is found in both leach liquors from ores and in secondary sources at a lower $\mathrm{pH}$. Most of the work in hydrometallurgy is focused on extracting metals at $\mathrm{pH}$ values as low as possible [45]. Mixtures of extractants have been employed by different investigators to extract $\mathrm{Ni}^{2+}, \mathrm{Co}^{2+}, \mathrm{Pb}^{2+}$ and $\mathrm{Cd}^{2+}$ at relatively low $\mathrm{pH}(1-3)$ [46-48], however, there are few single extractants that can extract metal ions efficiently at lower $\mathrm{pH}$ values. Most extractants are used commercially and are not effective for the recovery of these metals in a highly acidic medium ( $\mathrm{pH}<4)$ [45, 46, 49-55]. 2-(diphenylphosphino)aminopyridine showed good efficiency and affinity for metal ions at $\mathrm{pH} 2$ according to the results obtained, making it suitable for solvent extractions in acidic media.

The nature of the extracted species was studied by evaluating the distribution ratio of metal picrates in the aqueous and organic phases. In this system, $\log D$ versus $\mathrm{pH}$ were plotted (Fig. 2), where $D$ is the distribution ratio of the concentration of each metal picrate. As shown in Figure 2, there was a deviation from linearity. This may be due to the different complexing effects and/or formation of protonated species of the ligand during extraction from the acidic solution.

The effect of ligand volume (organic phase) on the extraction of metal picrates was studied to determine the optimum value required for extraction. Table 2 shows the dependence of the recovery on the ligand solution volume (organic phase). The optimum ligand volume was determined as $2 \mathrm{ml}$ at $\mathrm{pH}$ 2. The extraction percentage values of $\mathrm{Ni}, \mathrm{Cd}$, $\mathrm{Cu}, \mathrm{Co}$ and $\mathrm{Pb}$ picrates were $97.9 \%, 99.3 \%$, $88.9 \%, 98.5 \%$ and $97.1 \%$, respectively, when $2 \mathrm{ml}$ of the solution of aminophosphine was used for the 
extraction. $\mathrm{E} \%$ values for $\mathrm{Ni}, \mathrm{Cd}, \mathrm{Co}$ and $\mathrm{Pb}$ picrates were quantitative. As shown in Table 2, the ligand volume did not significantly affect the recovery of metal ions.

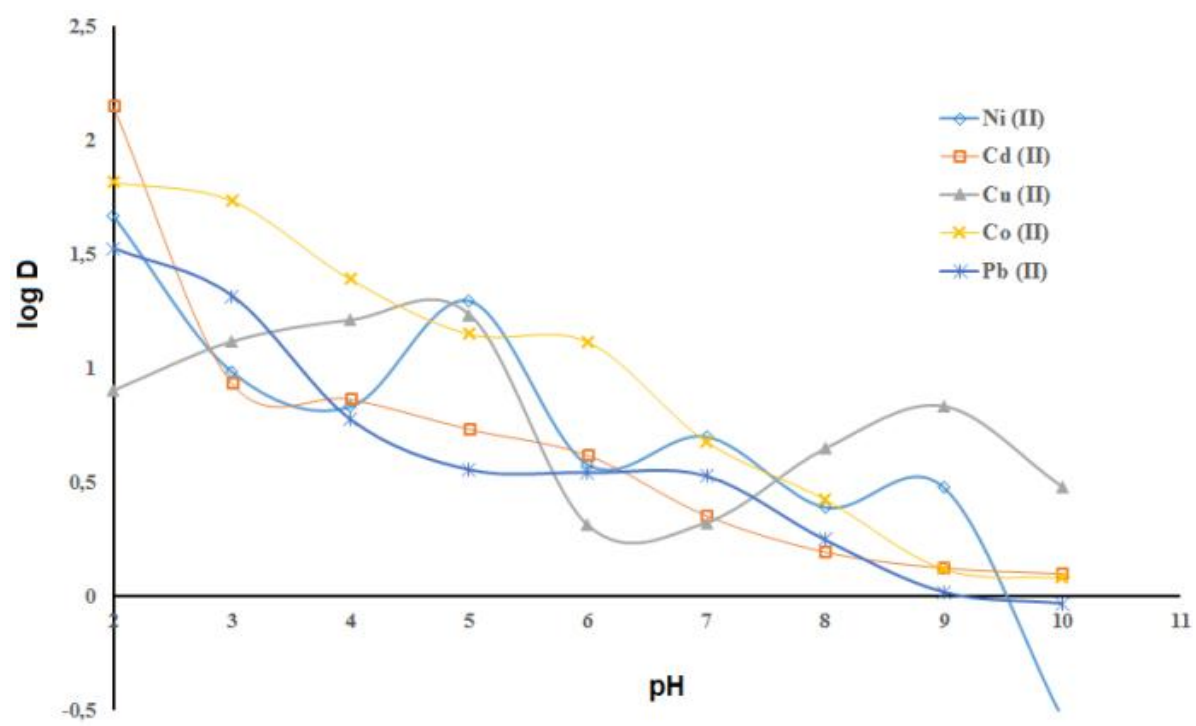

Fig. 2. Relationship between $\mathrm{pH}$ and $\log D$

Table 2

Effect of ligand solution volume on the extraction of metal picrates

\begin{tabular}{cccccc}
\hline \hline \multirow{2}{*}{$\begin{array}{l}\text { Ligand solution } \\
\text { volume }(\mathrm{ml})\end{array}$} & $\mathrm{Ni}^{2+}$ & $\mathrm{Cd}^{2+}$ & $\mathrm{Cu}^{2+}$ & $\mathrm{Co}^{2+}$ & $\mathrm{Pb}^{2+}$ \\
\cline { 2 - 6 } & $97.92 \pm 0.1$ & $99.30 \pm 0.3$ & $88.90 \pm 7.4$ & $98.50 \pm 0.2$ & $97.10 \pm 2.3$ \\
4 & $97.30 \pm 0.1$ & $96.91 \pm 1.2$ & $76.08 \pm 7.8$ & $92.86 \pm 0.4$ & $94.95 \pm 1.2$ \\
6 & $96.40 \pm 0.3$ & $97.10 \pm 1.2$ & $82.75 \pm 2.4$ & $93.11 \pm 0.8$ & $94.74 \pm 0.5$ \\
8 & $95.68 \pm 0.5$ & $97.49 \pm 0.9$ & $83.14 \pm 0.7$ & $93.11 \pm 0.6$ & $95.13 \pm 1.1$ \\
10 & $96.30 \pm 0.3$ & $95.56 \pm 1.9$ & $82.35 \pm 1.8$ & $90.23 \pm 1.4$ & $91.27 \pm 0.3$ \\
\hline \hline
\end{tabular}

T a b le 3

Quantitative antimicrobial assay results (zone of growth inhibition) of 2-(diphenylphosphino)aminopyridine at different concentrations

\begin{tabular}{llllll}
\hline \hline \multirow{2}{*}{$\left.\begin{array}{l}\mathrm{Ph}_{2} \mathrm{PNHPy} \\
\text { concentration } \\
(\text { mol. }\end{array} 1^{-1}\right)$} & \multicolumn{5}{c}{ Inhibition zone diameter [mm] } \\
\cline { 2 - 6 } & \multicolumn{4}{c}{ Gram negative bacteria } & \multicolumn{2}{c}{ Gram positive bacteria } \\
\cline { 2 - 6 } $1 \cdot 10^{-8}$ & E.coli & P.syringae & S.typhmurium & S.aureus & S.mutans \\
$1 \cdot 10^{-7}$ & 9.21 & 3.86 & 5.85 & 4.91 & 6.25 \\
$1 \cdot 10^{-6}$ & 11.28 & 6.27 & 8.32 & 6.29 & 9.78 \\
$1 \cdot 10^{-5}$ & 14.84 & 7.58 & 11.74 & 8.22 & 12.32 \\
$1 \cdot 10^{-4}$ & 16.32 & 9.27 & 14.27 & 9.16 & 15.27 \\
Control: DMSO & 0.0 & 0.0 & 0.0 & 11.48 & 17.12 \\
Gentamicin & 11.87 & 11.68 & 11.52 & 0.0 & 0.0 \\
Ampicillin & 12.26 & 10.21 & 12.92 & 12.36 & 11.92 \\
\hline \hline
\end{tabular}


The antibacterial activity of 2-(diphenylphosphino)aminopyridine at various concentrations was evaluated against Gram-positive and Gramnegative bacteria using the disc diffusion method. More than one organism was tested to increase the chance of detecting antibacterial activities. The compound was insoluble in water, so the assay was carried out using dimethylsulfoxide (DMSO) as solvent. DMSO was also used as a control to confirm that it did not inhibit bacterial growth. Commercially available standard drugs ampicillin and gentamicin were used as antibacterial controls and the results of the disc diffusion assay are summarized in Table 3. The presence of an inhibition zone clearly indicated the antibacterial effect of aminophosphine. The ligand showed high antibacterial activity against the investigated Grampositive and Gram-negative bacteria. The amount of ligand tested for antibacterial activity was essential. As shown in Table 3, the antibacterial activity of the aminophosphine increased with increasing ligand concentration. The antibacterial activities of the aminophosphine at concentrations of $10^{-5} \mathrm{M}$ and $10^{-4} \mathrm{M}$ were found to be higher than those of standard antibiotics against E. coli, S. typhmurium and S. mutans.

\section{MATERIALS AND METHODS}

Reactions were routinely carried out using Schlenk-line techniques under pure dry nitrogen gas. Solvents were dried and distilled prior to use. All other chemicals used were of analytical grade and did not require further purification. ${ }^{31} \mathrm{P}-\left\{{ }^{1} \mathrm{H}\right\}$ and ${ }^{1} \mathrm{H}$ NMR spectra were taken on a Bruker UltraShield-400 spectrophotometer. Infrared spectra were recorded on a Perkin Elmer FT-IR System Spectrum BX. Spectrophotometric measurements were performed using a Shimadzu UV-160 A UVvis spectrophotometer.

\subsection{Preparation of \\ 2-(diphenylphosphino)aminopyridine}

$\mathrm{Ph}_{2} \mathrm{PNHpy}$ was synthesised as in a previously reported procedure [35]. A mixture of 2aminopyridine (3.75 g, $39.84 \mathrm{mmol}$ ) and triethylamine $(5.5 \mathrm{ml}, 39.68 \mathrm{mmol})$ was dissolved in tetrahydrofuran $(20 \mathrm{ml})$. The solution was cooled to $0{ }^{\circ} \mathrm{C}$ and $\mathrm{Ph}_{2} \mathrm{PCl}(7.3 \mathrm{ml}, 39.70 \mathrm{mmol})$ was slowly added. The reaction mixture was stirred for $6 \mathrm{~h}$. After this time, the ammonium salt was separated by filtration and the solvent was removed under vacuum. The oily residue obtained was dissolved in tetrahydrofuran and precipitated with diethylether, producing $7.5 \mathrm{~g}$ of white powder (68\% yield). Found (calc. for $\mathrm{C}_{17} \mathrm{H}_{15} \mathrm{PN}_{2}$ ): $\mathrm{C}, 73.67$ (73.37); H, 5.21 (5.43); N, 9.83 (10.07). ${ }^{1} \mathrm{H}$ NMR $\left(\mathrm{CDCl}_{3}, \delta, \mathrm{ppm}\right): 5.36\left(\mathrm{~d}, \mathrm{NH}, 1 \mathrm{H}, \mathrm{J}_{\mathrm{PH}}=8 \mathrm{~Hz}\right), 6.72$ $\left(\mathrm{t}, \mathrm{C}_{5-\mathrm{H}}, 1 \mathrm{H}\right), 7.04\left(\mathrm{~d}, \mathrm{C}_{3-\mathrm{H}}, 1 \mathrm{H}\right), 7.28-7.50(\mathrm{~m}, \mathrm{Ph}$, $\left.\mathrm{C}_{4-\mathrm{H}}, 11 \mathrm{H}\right), 8.11\left(\mathrm{~d}, \mathrm{C}_{6-\mathrm{H}}, 1 \mathrm{H}\right) .{ }^{31} \mathrm{P}-\left\{{ }^{1} \mathrm{H}\right\}$ NMR $\left(\mathrm{CDCl}_{3}, \delta, \mathrm{ppm}\right): 25.86(\mathrm{~s}) . \mathrm{IR}\left(\mathrm{cm}^{-1}\right): 918(\mathrm{PN})$, $1434(\mathrm{PPh}), 3117(\mathrm{NH}), 1599(\mathrm{C}=\mathrm{N})$.

\subsection{Solvent extraction procedure}

$1 \times 10^{-3} \mathrm{M}$ aqueous solutions of the metal picrates were prepared according to literature [49]. $1 \times 10^{-3} \mathrm{M}$ solutions of 2-(diphenylphosphino)aminopyridine were prepared separately in dichloromethane and used as extractants. $2 \mathrm{ml}$ of the extractant solution was added to a $10 \mathrm{ml}$ volumetric flask that was then filled with dichloromethane. An organic solution $(10 \mathrm{ml})$ containing $2 \mathrm{ml}$ of ligand $\left(1 \times 10^{-3} \mathrm{M}\right)$, an aqueous solution $(10 \mathrm{ml})$ containing $2 \mathrm{ml}$ of the metal picrate solution $(1 \times$ $10^{-3} \mathrm{M}$ ) and $8 \mathrm{ml}$ of a buffer solution (for $\mathrm{pH}$ adjustment) were placed into a stoppered flask and stirred with a magnetic stirrer at $25^{\circ} \mathrm{C}$ for $1 \mathrm{~h}$ in a water jacket. The mixture was allowed to settle for $30 \mathrm{~min}$ to allow for phase separation. After phase separation, the metal picrate extraction values (E\%) in the aqueous phase were determined based on their absorbance by UV-Vis spectrophotometry using the following equation (Eq. 1).

$$
E \%=\left[\frac{A_{0}-A}{A_{0}}\right] \times 100
$$

where $A_{0}$ is the absorbance in the absence of the ligand and $A$ denotes the absorbance in the aqueous phase after extraction.

The $\mathrm{pH}$ of the aqueous solutions was maintained at $\mathrm{pH} 2-10$ using buffer solutions to investigate the effect of $\mathrm{pH}$ on $\mathrm{E} \%$. The extractant solutions with various volumes $(2,4,6,8$ and $10 \mathrm{ml})$ were added to $10 \mathrm{ml}$ volumetric flasks that were then filled with dichloromethane. Equal volumes $(10 \mathrm{ml})$ of the organic solution and aqueous solution were used to investigate the effect of the ligand solution volume on the extraction of metal ions at $\mathrm{pH} 2$.

\subsection{Antibacterial activity studies}

\subsubsection{Microorganisms tested}

Escherichia coli (E. coli) ATCC 25922, Staphylococcus aureus (S. aureus) ATCC 25923, Pseudomonas syringae $p v$. tomato ( $P$. syringae) DC300, Salmonella enterica serotype Typhmurium 
(S. typhmurium) SL 1344 and Streptococcus mutans (S. mutans) ATCC 25175 were the microorganisms tested. Bacteria were maintained on $\mathrm{Lu}-$ ria Bertoni (LB) agar culture medium at $4{ }^{\circ} \mathrm{C}$. All the tested microorganisms were subcultured on appropriate medium at $37^{\circ} \mathrm{C}$ for $24 \mathrm{~h}$.

\subsubsection{Activity assay}

Antibacterial activities of the synthesized $\mathrm{Ph}_{2} \mathrm{PNHpy}$ ligand against the Gram-positive and Gram-negative bacteria were determined using the disc diffusion method. 0.5 McFarland standard was used as a reference to adjust the turbidity of the microorganisms. The tested compound was dissolved in DMSO, which has no inhibition activity. Samples were sterilized by UV irradiation for 30 min before incubation. Microorganism suspensions of $100 \mu \mathrm{l}$ were inoculated $(1 \times 108 \mathrm{CFU} / \mathrm{ml})$ onto Müller-Hinton medium. Filter discs $(6 \mathrm{~mm}$ in diameter) containing various concentrations of the $\mathrm{Ph}_{2}$ PNHpy $\left(10^{-8} \mathrm{M}, 10^{-7} \mathrm{M}, 10^{-6} \mathrm{M}, 10^{-5} \mathrm{M}\right.$ and $10^{-4} \mathrm{M}$ ) were placed on inoculated Petri plates and incubated at $37^{\circ} \mathrm{C}$ for $24 \mathrm{~h}$. A DMSO-only disc was used as a negative control. Ampicillin and gentamicin were used as standard drugs for the bacteria. The diameter of the inhibition zone was calculated after incubation. All experiments were repeated in triplicate and mean values were calculated.

\section{CONCLUSIONS}

2-(diphenylphosphino)aminopyridine effectively extracted metal ions including $\mathrm{Ni}^{2+}, \mathrm{Cu}^{2+}$, $\mathrm{Co}^{2+}, \mathrm{Pb}^{2+}$ and $\mathrm{Cd}^{2+}$ from the aqueous phase to the organic phase. The maximum E\% values of nickel, cadmium, cobalt and lead picrates were $97.9 \%$, $99.3 \%, 98.5 \%$ and $97.1 \%$, respectively, at $\mathrm{pH} \mathrm{2,}$ while the maximum $\mathrm{E} \%$ value of copper picrate was $94.5 \%$ at $\mathrm{pH}$ 5. This makes the ligand suitable for solvent extraction at a low $\mathrm{pH}$. The aminophosphine was also observed to have good antibacterial activity against Escherichia coli ATCC 25922, Staphylococcus aureus ATCC 25923, Pseudomonas syringae pv. tomato DC300, Salmonella enterica serotype Typhmurium SL 1344 and Streptococcus mutans ATCC 25175.

Acknowledgements. This study was supported financially by the Research Projects Unit of Nigde Ömer Halisdemir University with project no FEB 2012/07. The authors would like to thank Dr Vefa Muradoğlu. The authors declare no conflict of interest.

\section{REFERENCES}

[1] M. Jaishankar, T. Tseten, N. Anbalagan, B. B. Mathew, K. N. Beeregowda, Toxicity, mechanism and health effects of some heavy metals, Interdiscip. Toxicol, 7, 6072 (2014). DOI: 10.2478/intox-2014-0009

[2] G. U. Akkuş, E. Al, S. E. Korcan, Selective extraction of toxic heavy metals and biological activity studies using pyrimidylthioamide functionalised calix[4]arene, Supramo. Chem., 27, 522-526 (2015).

DOI: https://doi.org/10.1080/10610278.2015.1020944

[3] Y. H. Ibrahim, A. A. Shakour, N. M. Abdel-Latif, N. M. El-Taieb, Assessment of heavy metal levels in the environment, Egypt, J. Am. Sci., 7 (12), 148-153 (2011).

[4] M. Dutta, D. Das, Recent developments in fluorescent sensors for trace-level determination of toxic-metal ions, Trends Anal. Chem., 32, 113-132 (2012). DOI: https://doi.org/10.1016/j.trac.2011.08.010

[5] A. A. Bhatti, A. A. Bhatti, I. B. Solangi, S. Memon, Pb ${ }^{2+}$ adsorption behavior of calix[4]arene based Merrifield Resin, Desalin.Water Treat., 51, 4666-4674 (2013). DOI: https://doi.org/10.1080/19443994.2013.769757

[6] M. Cegłowski, G. Schroeder, Removal of heavy metal ions with the use of chelating polymers obtained by grafting pyridine-pyrazole ligands onto polymethylhydrosiloxane, Chem. Eng. J., 259, 885-893 (2015).

DOI: https://doi.org/10.1016/j.cej.2014.08.058

[7] F. Fu, Q. Wang, Removal of heavy metal ions from wastewaters: A review. J. Environ. Manage, 92, 407418 (2011).

DOI: https://doi.org/10.1016/j.jenvman.2010.11.011

[8] S. Khan, Q. Cao, Y. M. Zheng, Y. Z. Huang, Y. G. Zhu, Health risks of heavy metals in contaminated soils and food crops irrigated with wastewater in Beijing, China, Environmental Pollution, 152, 686-692 (2008). DOI:10.1016/j.envpol.2007.06.056

[9] Y. Liu, H. S. Jeon, M. S. Lee, Solvent extraction of Pr and $\mathrm{Nd}$ from chloride solutions using ternary extractant system of Cyanex 272, Alamine 336 and TBP, J. Ind. and Eng. Chem., 31, 74-79 (2015).

DOI: https://doi.org/10.1016/j.jiec.2015.06.009

[10] Y. A. El-Nadi, Lanthanum and neodymium from Egyptian monazite: Synergistic extractive separation using organophosphorus reagents, Hydrometallurgy, 119-120, 23-29 (2012).

DOI: https://doi.org/10.1016/j.hydromet.2012.03.003

[11] S. Zhu, H. Hu, J. Hu, J. Li, F. Hu, Y. Wang, Structural insights into the coordination and extraction mechanism of nickel(II) with dinonylnaphthalene sulfonic acid and n-hexyl 3-pyridinecarboxylate ester as extractants, $J$. Chin. Chem. Soc., 64, 1294-1302 (2017). DOI: $10.1002 /$ jccs.201700199

[12] D. Sihem, B. Djamel, Extraction of copper(II) with di(2ethylhexyl)phosphoric acid from perchlorate medium, Analytical Chemistry Letters, 5:4, 198-205 (2015). DOI: $10.1080 / 22297928.2015 .1116406$

[13] E. Bidari, M. Irannajad, M. Gharabaghi, Investigation of the influence of acetate ions on cadmium extraction with 
D2EHPA, Hydrometallurgy, 144-145, 129-132 (2014). DOI: https://doi.org/10.1016/j.hydromet.2014.02.004

[14] V. Kumar, M. Kumar, M. Kumar, J. Jeong, J. Lee, Solvent extraction of cadmium from sulfate solution with di-(2-ethylhexyl) phosphoric acid diluted in kerosene, Hydrometallurgy, 96, 230-234 (2009). DOI: https://doi.org/10.1016/j.hydromet.2008.10.010

[15] D. Cholico-Gonzalez, A. Chagnes, G. Cote, M. AvilaRodriguez, Separation of $\mathrm{Co}(\mathrm{II})$ and $\mathrm{Ni}(\mathrm{II})$ from aqueous solutions by bis(2,4,4-trimethylpentyl)phosphinic acid (Cyanex 272) using trihexyl(tetradecyl)phosphonium chloride (Cyphos IL 101) as solvent, J. Mol. Liq., 209, 203-208 (2015).

DOI: https://doi.org/10.1016/j.molliq.2015.05.048

[16] B. R. Reddy, D. N. Priya, J. R. Kumar, Solvent extraction of cadmium(II) from sulphate solutions using TOPS 99, PC 88A, Cyanex 272 and their mixtures, Hydrometallurgy, 74, 277-283 (2004).

DOI: https://doi.org/10.1016/j.hydromet.2004.06.001

[17] B. R. Reddy, D. N. Priya, Chloride leaching and solvent extraction of cadmium, cobalt and nickel from spent nickel-cadmium batteries, using Cyanex 923 and 272, J. Power Sources, 161, 1428-1434 (2006).

DOI: https://doi.org/10.1016/j.jpowsour.2006.05.044

[18] N. A. Grigorieva, G. L. Pashkov, I. Y. Fleitlikh, L. K. Nikiforova, M. A. Pleshkov, Nickel extraction from sulfate media with Cyanex 301 in the presence of electron donor additives, Hydrometallurgy, 105, 82-88 (2010). DOI: https://doi.org/10.1016/j.hydromet.2010.08.001

[19] B. Gupta, A. Deep, S. N. Tandon, Recovery of chromium and nickel from industrial waste, Ind. Eng. Chem. Res, 41, 2948-2952 (2002).

DOI: https://pubs.acs.org/doi/pdf/10.1021/ie010934b

[20] B. Gupta, A. Deep, P. Malik, Extraction and recovery of cadmium using Cyanex 923, Hydrometallurgy, 61, 6571 (2001).

DOI: https://doi.org/10.1016/S0304-386X(01)00157-8

[21] B. Menoyo, M. P. Elizalde, A. Almela, Extraction of lead by Cyanex 302 from phosphoric acid media, Solvent Extr. Ion Exch., 19, 677-698 (2001). DOI: https://www.tandfonline.com/doi/abs/10.1081/SEI100103815

[22] K. Staszak, K. Wieszczycka, P. Burmistrzak, Removal of Cadmium(II) Ions from chloride solutions by Cyanex 301 and Cyanex 302, Sep. Sci. Technol, 46, 1495-1502 (2011).

DOI: https://doi.org/10.1080/01496395.2011.563258

[23] S. Choi, V. T. Nguyen, J. Lee, H. Kang, B. D. Pandey, Liquid-liquid extraction of $\mathrm{Cd}(\mathrm{II})$ from pure and $\mathrm{Ni} / \mathrm{Cd}$ acidic chloride media using Cyanex 921: A selective treatment of hazardous leachate of spent $\mathrm{Ni}-\mathrm{Cd}$ batteries, J. Hazard. Mater., 278, 258-266 (2014).

DOI: 10.1016/j.jhazmat.2014.06.013

[24] R. A. Cherkasov, A. R. Garifzyanov, E. B. Bazanova, R. R. Davletshin, S. V. Leont'eva, Liquid extraction of some rare earth elements with aminomethylphosphine oxides, Russ. J. Gen. Chem, 82, 33-42 (2012). DOI: $10.1134 / \mathrm{S} 1070363212010069$

[25] M. Tian, F. Mu. Q. Jia, X. Quan, W. Liao, Solvent extraction studies of zinc(II) and cadmium(II) from a chloride medium with mixtures of neutral organophosphorus extractants and amine extractants, J. Chem. Eng. Data, 56, 2225-2229 (2011). DOI: 10.1021/je101245d

[26] S. Pratihar, R. Pegu, A. K. Guha, B. Sarma, Pd(II) coordinated deprotonated diphenyl phosphino amino pyridine: reactivity towards solvent, base, and acid, Dalton Trans., 43, 17136-17144 (2014). DOI: $10.1039 / \mathrm{C} 4 \mathrm{DT} 01665 \mathrm{C}$

[27] Ö. Sarıöz, Y. Sürme, V. Muradoğlu, Heavy-metal extraction capability of chalcogenoic aminophosphines derived from 1-amino-4-methylpiperazine, Chem. Pap, 67 (10), 1345-1349 (2013).

DOI: $10.2478 / \mathrm{s} 11696-013-0372-2$

[28] A. Alsaygh, J. Al-Humaidi, I. Al-Najjar, Synthesis of some new pyridine-2-yl-benzylidene-imines, Int. J. Org. Chem., 4, 116-212 (2014). DOI: $10.4236 /$ ijoc.2014.42013

[29] M. S. Abbady, M. S. K. Youssef, Synthesis and biological activity of some new pyridines, pyrans, and indazoles containing pyrazolone moiety, Med. Chem. Res., 23, 3558-3568 (2014). DOI: $10.1007 / \mathrm{s} 00044-014-0935-\mathrm{y}$

[30] W. Xue, C. Zhang, Z. Zeng, X. Chen, Liquid-liquid equilibria for systems of 1-butanol + water +2,6-diaminopyridine and 1-butanol + water +2 -aminopyridine, J. Chem. Eng. Data, 54, 1266-1270 (2009). DOI: $10.1021 / \mathrm{je} 8007843$

[31] R. G. Mohamed, F. M. Elantabli, N. H. Helal, S. M. ElMedani, New group 6 metal carbonyl complexes with 4,5-dimethyl-N,Nbis(pyridine-2-yl-methylene)benzene1,2-diimine Schiff base: Synthesis, spectral, cyclic voltammetry and biological activity studies, Spectrochim. Acta Part A, 141, 316-326 (2015). DOI:10.1016/j.saa.2015.01.054

[32] H. T. Al-Masri, B. M. Mohamed, Z. Moussa, M. H. Alkordi, Synthesis and characterization of carbonyl group-6-metal derivatives with ligand N,N-bis(diphenylphosphino)naphthalen-1-amine (=N-(Diphenylphosphino)-N-naphthalen-1-yl-P,P-diphenylphosphinous Amide). Molecular structure of cis-tetracarbonyl[N(diphenylphosphino-kP)-Nnaphthalen-1-yl-P,P-diphenylphosphinous amide-kP] molybdenum (cis$\left.\left[\mathrm{Mo}(\mathrm{CO})_{4}\left\{\mathrm{C}_{10} \mathrm{H}_{7}-1-\mathrm{N}\left(\mathrm{PPh}_{2}\right)_{2}\right\}\right]\right)$, Helv. Chim. Acta, 96, 738-746 (2013). DOI: 10.1002/hlca.201200315

[33] M. F. Fillat, M. C. Gimeno, A. Laguna, E. Latorre, L. Ortego, M. D. Villacampa, Synthesis, structure and bactericide activity of (aminophosphane)gold(I) thiolate complexes, Eur. J. Inorg. Chem., 9, 1487-1495 (2011). DOI: $10.1002 /$ jic.201001195

[34] L. Ortego, J. Gonzalo-Asensio, A. Laguna, M. D. Villacampa, M. C. Gimeno, (Aminophosphane)gold(I) and silver(I) complexes as antibacterial agents, J. Inorg. Biochem., 146, 19-27 (2015). DOI: https://doi.org/10.1016/j.jinorgbio.2015.01.007

[35] P. A. Aguirre, C. A. Lagos, S. A. Moya, C. Zuniga, C. Vera-Oyarce, E. Sola, G. Peris, J. C. Bayon, Methoxycarbonylation of olefins catalyzed by palladium complexes bearing P,N-donor ligands, Dalton Trans, 5419-5426 (2007). DOI: 10.1039/b704615b

[36] S. M. Aucott, A. M. Z. Slawin, J. D. Woollins, The coordination chemistry of 2-(diphenylphosphinoamino) pyridine, J. Chem. Soc. Dalton Trans., 2559-2575 (2000). DOI: 10.1039/b003294h 
[37] M. Alyapyshev, V. Babain, N. Borisova, I. Eliseev, D. Kirsanov, A. Kostin, A. Legin, M. Reshetova, Z. Smirnova, 2,2'-Dipyridyl-6,6'-dicarboxylic acid diamides: Synthesis, complexation and extraction properties, Polyhedron, 29, 1998-2005 (2010). DOI: https://doi.org/10.1016/j.poly.2010.03.021

[38] M. L. Clarke, A. M. Z. Slawin, M. V. Wheatley, J. D. Woollins, Synthesis and structure of novel rhodium complexes of multi-functionalised amine-phosphine ligands, J. Chem. Soc., Dalton Trans., 3421-2429 (2001). DOI: $10.1039 / \mathrm{b} 104523 \mathrm{~g}$

[39] S. M. Aucott, A. M. Z. Slawin, J. D. Woollins, Synthesis, structure and properties of new pyridylaminophosphine complexes, Phosphorus. Sulfur and Silicon, 124-125, 473-476 (1997). DOI: $10.1080 / 10426509708545662$

[40] C. Holzhacker, B. Stöger, M. D. Carvalho, L. P. Ferreira, E. Pittenauer, G. Allmaier, L. F. Veiros, S. Realista, A. Gil, M. J. Calhorda, D. Müler, K. Kirchner, Synthesis and reactivity of TADDOL-based chiral Fe(II) PNP pincer complexes-solution equilibria between $\kappa 2 \mathrm{P}, \mathrm{N}-$ and $\kappa 3 \mathrm{P}, \mathrm{N}, \mathrm{P}-$ bound PNP pincer ligands, Dalton Trans, 44, 13071-13086 (2015). DOI: $10.1039 / \mathrm{c} 5 \mathrm{dt} 00832 \mathrm{~h}$

[41] W. Lackner-Warton, S. Tanaka, C. M. Standfest-Hauser, Ö. Öztopcu, J. Hsieh, K. Mereiter, K. Kirchner, Synthesis and characterization of ruthenium $\mathrm{p}$-cymene complexes bearing bidentate $\mathrm{P}-\mathrm{N}$ and $\mathrm{E}-\mathrm{N}$ ligands $(\mathrm{E}=\mathrm{S}$, Se) based on 2-aminopyridine, Polyhedron, 29, 3097$3102(2010)$.

DOI: https://doi.org/10.1016/j.poly.2010.08.014

[42] E. S. Tabei, H. Samouei, M. Rashidi, Multiple hydrogen bondings in a platinum complex, Dalton Trans, 40, 11385-11388 (2011). DOI:10.1039/c1dt11298h

[43] J. R. Turkington, P. J. Bailey, J. B. Love, A. M. Wilson, P. A. Tasker, Exploiting outer-sphere interactions to enhance metal recovery by solvent extraction, Chem. Commun., 49, 1891-1899 (2013). DOI: $10.1039 / \mathrm{c} 2 \mathrm{cc} 37874 \mathrm{~d}$

[44] A. Almela, M. P. Elizalde, Solvent extraction of cadmium(II) from acidic media by Cyanex 302, Hydrometallurgy, 37, 47-57 (1995). DOI: https://doi.org/10.1016/0304-386X(94)00012-R

[45] S. Chauhan, T. Patel, A Review on solvent extraction of nickel, Int. J. Eng. Res. Technol, 3, 1315-1322 (2014). https://www.ijert.org/component/search/?searchword=A $\% 20$ Review\%20on\%20solvent $\% 20$ extraction $\% 20$ of\%20 nickel\&searchphrase $=$ all $\&$ Itemid $=451$

[46] M. J. Jung, P. Venkateswaran, Y. S. Lee, Solvent extraction of nickel(II) ions from aqueous solutions using triethylamine as extractant, J. Ind. Eng. Chem., 14, 110115 (2008).
DOI: https://doi.org/10.1016/j.jiec.2007.08.004

[47] A. Cerpa, F. J. Alguacil, Separation of cobalt and nickel from acidic sulfate solutions using mixtures of di(2ethylhexyl)phosphoric acid (DP-8R) and hydroxyoxime (ACORGA M5640), J. Chem. Technol. Biotechnol., 79, 455-460 (2014).

DOI: http://onlinelibrary.wiley.com/doi/10.1002/jctb.960/pdf

[48] Y. Liu, M. Lee, Separation of Co and Ni from a chloride leach solutions of laterite ore by solvent extraction with extractant mixtures, J. Ind. Eng. Chem, 28, 322-327 (2015). DOI: https://doi.org/10.1016/j.jiec.2015.03.010

[49] B. Dede, F. Karipcin, F. Arabal1, M. Cengiz, Synthesis, structure, and solvent-extraction properties of tridentate oxime ligands and their cobalt(II), nickel(II), copper(II), zinc(II) complexes, Chem. Pap., 64, 25-33 (2010). https://link.springer.com/content/pdf/10.2478\%2Fs1169 6-009-0095-6.pdf

[50] C. P Mane, M. A. Anuse, Extraction behaviour of 2octylaminopyridine towards lead(II) from succinate media and its separation from other toxic metals, J. Hazard. Mater, 152, 1146-1154 (2008). DOI: https://doi.org/10.1016/j.jhazmat.2007.07.119

[51] X. Chen, T. Zhou, J. Kong, H. Fang, Y.Chen, Separation and recovery of metal values from leach liquor of waste lithium nickel cobalt manganese oxide based cathodes, Sep. Purif. Technol., 41, 76-83 (2015).

DOI: https://doi.org/10.1016/j.seppur.2014.11.039

[52] T. N. Shilimkar, M. A. Anuse, Rapid extraction of lead(II) from succinate media with n-octylaniline in toluene, Sep. Purif. Technol, 26, 185-193 (2002). DOI: https://doi.org/10.1016/S1383-5866(01)00166-6

[53] T. Hayashita, T. Higuchi, H. Sawano, A. P. Marchand, K. A. Kumar, S. G. Bott, K. Mlinaric-Majerski, T. Sumanovac, N. S. A. Elkarim, H. Hwang, G. G. Talanova and R. A. Bartsch, Molecular design of lipophilic disalicylic acid compounds with varying spacers for selective lead(II) extraction, Talanta, 52, 385-396 (2000). DOI: https://doi.org/10.1016/S00399140(00)00359-3

[54] K. Ikeda, S. Abe, Liquid-liquid extraction of cationic metal complexes with p-nonylphenol solvent: Application to crown and thiacrown ether complexes of lead(II) and copper(II), Anal. Chim. Acta, 363, 165-170 (1998). DOI: https://doi.org/10.1016/S0003-2670(98)00126-3

[55] M. C. Olivier, C. Dorfling, J. J. Eksteen, Evaluating a solvent extraction process route incorporating nickel preloading of Cyanex 272 for the removal of cobalt and iron from nickel sulphate solutions, Miner. Eng., 27-28, 37-51 (2012). DOI: https://doi.org/10.1016/j.mineng.2011.12.006 